\title{
ArcheoSciences
}

Revue d'archéométrie

\section{Gold technology of the ancient Scythians - gold from the kurgan Arzhan 2, Tuva}

La technologie de l'or chez les Scythes anciens - l'or du kurgan Arjan 2, Touva

\section{Barbara Armbruster}

\section{(2) OpenEdition}

12 Journals

Electronic version

URL: https://journals.openedition.org/archeosciences/2193

DOI: 10.4000/archeosciences. 2193

ISBN: 978-2-7535-1598-7

ISSN: 2104-3728

Publisher

Presses universitaires de Rennes

\section{Printed version}

Date of publication: 31 December 2009

Number of pages: 187-193

ISBN: 978-2-7535-1181-1

ISSN: $1960-1360$

\section{Electronic reference}

Barbara Armbruster, "Gold technology of the ancient Scythians - gold from the kurgan Arzhan 2,

Tuva", ArcheoSciences [Online], 33 | 2009, Online since 10 December 2012, connection on 01 February 2022. URL: http://journals.openedition.org/archeosciences/2193 ; DOI: https://doi.org/10.4000/ archeosciences. 2193 


\title{
Gold technology of the ancient Scythians - gold from the kurgan Arzhan 2, Tuva
}

\author{
La technologie de l'or chez les Scythes anciens - l'or du kurgan Arjan 2, Touva
}

\author{
Barbara Armbruster*
}

\begin{abstract}
In 2000-2003, a 'royal' burial site in Tuva Republic, Siberia, dating to early Scythian times, was excavated by a joint German-Russian research program. Thousands of gold articles were discovered in the wooden chamber of 'royal' burial no. 5 , dated to the late $7^{\text {th }}$ century BC. The majority of these ornaments are decorated in the Scythian animal style. The study of the technological aspects reveals the variety of manufacturing techniques and designs employed for these extremely rich ornaments, and provides an insight into the complexity of the art of the early Scythian goldsmiths at the end of the $7^{\text {th }}$ century BC. This paper aims to present the large variety of distinct processes used in the manufacture of these gold artefacts. The technical expertise and the equipment at the disposal of the Early Iron Age craftsmen can be inferred from tool marks and analysis of surface structures. The early date of these finds, demonstrated by a combination of radiocarbon and dendrochronology, supports the assumption that this particular, sophisticated style of early Scythian metal work originated in the Tuva region.
\end{abstract}

Résumé : Une sépulture princière, datée du début de la période Scythe, a été fouillée en 2002-2003 dans la République de Touva, Sibérie, dans le cadre d'un programme de recherche germano-Russe. Des milliers d'objets en or ont été découverts dans la chambre funéraire de la sépulture $n^{\circ} 5$, datant du vIr siècle av. J.-C. La majorité de ces parures est décorée dans le style animalier Scythe. L'étude technologique a révélé la variété des techniques de fabrication et des motifs employés pour ces ornements extrêmement riches. Elle a aussi donné un aperçu de la complexité de l'art des orfevres Scythes à la fin du VII siècle av. J.-C. Cet article vise à présenter la grande variété des procédés distincts utilisés dans la fabrication de ces objets en or. La compétence technique et l'équipement à la disposition de l'artisan à l'Âge du Fer ancien peuvent être déduits des traces d'outils et de l'analyse des structures de surface. La précocité de ces trouvailles, démontrée par la combinaison de la datation radiocarbone avec la dendrochronologie, soutient l'hypothèse que ce style particulier et sophistiqué du travail du métal au début de l'époque Scythe trouverait son origine dans la région de Touva.

Keywords: Scythians, goldwork, Arzhan 2, manufacture, tool marks.

Mots-clés : Scythes, orfevrerie, Arjan 2, fabrication, traces d'outils.

\section{INTRODUCTION}

This paper deals with early Scythian precious metal technology, more precisely with the manufacture of the gold jewellery and ornamented weapons buried in the kurgan (burial mound) of Arzhan 2 in the north of the Republic of Tuva, in Siberia. One kurgan of this important Scythian royal necropolis was fully excavated from 2000 to 2003 as part of a German-Russian research program, headed by Hermann Parzinger and Anatoli Nagler (German Archaeological Institute, Berlin), as well as by Konstantin Chugunov (State Hermitage, Saint Petersburg) (Chugunov

*TRACES - UMR 5608 du CNRS - Maison de la Recherche, Université de Toulouse Le Mirail, 31058 Toulouse cedex. (barbara.armbruster@univtlse2.fr) 
et al., 2003; Menghin and Parzinger, 2007). Arzhan, in the district of Turan, is located in a plain where hundreds of kurgans are arranged in alignments. The kurgan Arzhan 2, which is nearly $80 \mathrm{~m}$ in diameter and more than $2 \mathrm{~m}$ in height, consisted of a platform constructed from stone slabs, as it is characteristic of the early Scythian period. The wooden chamber of the burial no. 5 was dated by radiocarbon and dendrochronology to the $2^{\text {nd }}$ half of the $7^{\text {th }}$ century BC. During the excavations of 2001, more than 5700 gold items were discovered in the undisturbed royal burial no. 5 (Chugunov, 2004; Chugunov et al., 2006). The results of current research on Arzhan 2 are forthcoming (Chugunov et al., 2010).

The two individuals in the prestigious burial no. 5, a man and a woman, were literary covered with gold. They were adorned with personal ornaments, such as torcs, necklaces, ear ornaments, pendants and pins. Gold also embellished the head-dress and boots, while a large number of appliqués covered the dress. The man's upper garment, clearly a cape, was adorned by about 2500 small cast panther figures, while the woman's cape was covered by much lighter, but aesthetically identical, panther figures worked in pressed sheet. In addition to gold beads, beads of different materials, such as carnelian, garnet, glass paste, malachite, and turquoise, are also present in the ensemble of personal ornaments. Other gold products, such as a miniature cup, a quiver and its carrying belt, as well as a wooden bowl with its handle covered with gold, are also part of this extraordinary discovery. Finally, iron weapons decorated with gold and silver inlay, such as daggers, knives, arrow-heads and a battle-axe form yet another category of these precious grave goods. The majority are decorated in the Scythian animal style.

A general problem related to the scientific study of early Scythian gold lies in the fact that precious metal artefacts are not known from hoards or settlement sites, but exclusively from funerary contexts, or as isolated objects, presumably from looted tombs. Scythian gold work from Siberia is particularly well known due to the Siberian collection of Peter the Great, on display in the State Hermitage Museum, St Petersburg (Schiltz, 1994; Popescu et al., 2001). International exhibitions showed some Scythian gold ornaments from Siberia dating to the $7^{\text {th }}$ and $6^{\text {th }}$ centuries $\mathrm{BC}$, such as the splendid rolled panther from Kélermes, or other animal figures, like the deer from Kostromslaïa (Busch, 1993; Popescu, 2001). However, the undisturbed tomb from Arzhan 2 represents the most luxuriant Siberian grave of the early Scythian period with regards to the number and combination of artefacts, as well as to the variety of different styles present, allowing one to distinguish different workshop traditions. The grave goods provide evidence of the high quality of the gold work in both aesthetical and technical terms (Armbruster, 2010). A significant part of the gold objects bear traces of wear, proving that they were used. However, there are also items without any traces of wear, which still maintain rough edges that make them unsuitable for use. They were most probably especially made for the burial and its ceremony, as is known in the case of the gold work from the early Celtic princely grave from EberdingenHochdorf, Ludwigsburg, Germany (Biel, 1985).

\section{WORKSHOP AND TECHNICAL KNOWLEDGE}

For the $7^{\text {th }}$ century BC, there are no written or iconographic sources available to inform us about the technical skill of the Scythian goldsmiths. That is why our knowledge of techniques is based above all on the study of archaeological artefacts with the help of analogies, experiments and material sciences. Tool marks and surface textures on the gold work from Arzhan 2 testify to the advanced technological knowledge of the goldsmiths and their well equipped workshops. However, no evidence of any early Scythian goldsmith workshop has ever been found. They must have consisted of a set of specialised tools and furnaces fanned with bellows in order to achieve a temperature of about $1000^{\circ} \mathrm{C}$, necessary for the melting of gold with a low silver or copper content. The furnaces must have been equipped with adequate tuyères and controlled air draft. Analyses of tool marks confirmed the following workshop equipment:

A pair of scales and weights are assumed to have been present for measuring. For casting, annealing and soldering, a furnace with bellows, charcoal, crucible, casting mould (clay or stone), and tongs (wood or iron) were needed, and a blow-pipe was probably also used. Plastic shaping was executed with hammers and anvils (stone or iron), and with dies (bronze or hard wood). The bending of wire, particularly of filigree elements, involves some sort of pliers. Decoration techniques required punches, scrapers, engraving tools, and chisels (hard iron or steel). Finishing could have been carried out with grinding stones, sand, ashes and acids. Ethnographic analogies demonstrate that in the nomadic lifestyle these tools can be transported in a sack or chest over long distances (Armbruster, 1995).

Before manufacturing an object, the goldsmith first developed a concept. In the case of the complex Scythian animal style, he first had to sketch the outline of the desired motif. Gold objects from Arzhan bear tool marks resulting from outlines. Any gold work starts from a cast ingot. Gold must be melted in a crucible and cast in a mould. For the gold from Tuva, two methods are evident. Ingot casting was used 
for preliminary products; then, the cast ingot was transformed by plastic shaping techniques in order to obtain wire or sheet. A large number of the Arzhan gold items consist of an assemblage of sheet and wire work.

\section{Casting}

However, lost wax casting was used for massive objects decorated with the complex relief motifs. Examples of such cast ornamental objects are the man's neck-ring and the woman's pectoral, pins, clasps, and waist buckles (Fig. 1), and various belt and strap elements. In addition to the animal figures that are worked fully in three dimensions (e.g. big cats, ibexes, deer, and eagles), other zoomorphic representations are realised individually in bas-relief, or arranged as animal groups integrated in the metal surface, occupying it entirely (e.g. boars, camels, big cats, deer, horses).

Flat figures cut out of thick gold sheet are another type of animal art occurring in Arzhan 2 (e.g. deer, horse, and ibex). The Scythian animal style appears in both a naturalistic version and a more or less stylised one.

\section{Sheet work}

Sheet metal and wire were produced through plastic shaping with a hammer and anvil. Repeated annealing prevented the gold from getting hard and brittle. The animal style sheet ornaments were executed by cutting the silhouette of the desired object using a chisel. Holes were formed with the help of a conical instrument. Chisels and engraving implements were used to remove metal. Sheet metal and wire were joined to create jewellery by soldering, as, for instance, in the case of complex ear-ornaments.

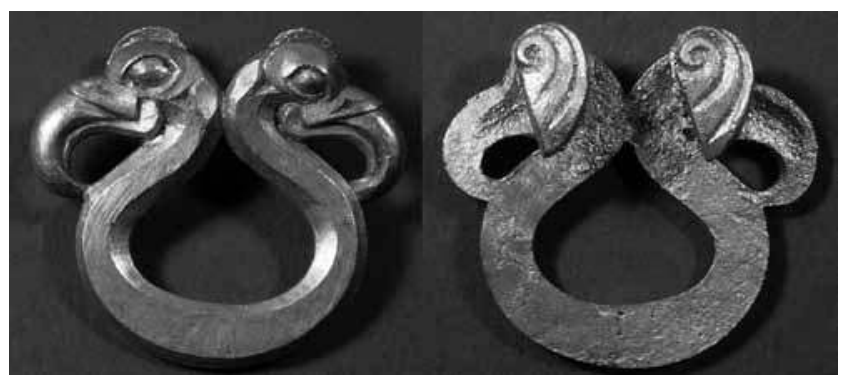

Figure 1: (See colour plate) Lost wax casting with 'kerbschnitt' relief, waist buckle.

Figure 1 : (Voir planche couleur) Fonte à la cire perdue avec relief 'kerbschnitt', boucle de ceinture.

\section{Engraving and openwork}

Several decorative techniques were applied in the early Scythian gold work from Arzhan in addition to the predominant method employed for ornaments cast in relief. Less complicated decorations were executed by engraving and cut in open work (Fig. 3). Engraving is a cutting technique that requires hardened steel tools to remove metal chips. Such hardened tools were needed for engraving certain gold decorations, as well as for preparing the grooves for precious metal inlay in the iron surfaces. Although no steel tools are known from that period, small steel scrapers were most probably used. Inlay was used to embellish the iron artefacts.

\section{Pressed sheet technique for serial production}

Chasing and pressed sheet are plastic deformation techniques also employed for decoration. The tools used for chasing are punches, chisels, and an elastic working surface, such as a chasing cement or thick leather. Only a single object from Arzhan 2, a panther figure, is definitely chased.

In contrast, thousands of small sheet panthers were realised by the pressed sheet technique using dies (Fig. 2b) (Armbruster, 2003). The sheet's relief is pushed with a pointed tool while the gold metal is positioned over the die. The use of dies serves for the manufacture of a series of pieces with little weight, but much optical effect. The small panther figures of the garment of the princess are examples of the pressed sheet technique. Another technique of pressed relief on sheet decoration is also present, using the carved relief of a wooden fitting as a die and producing single objects. The unique ornamental quiver and the handle of a wooden bowl

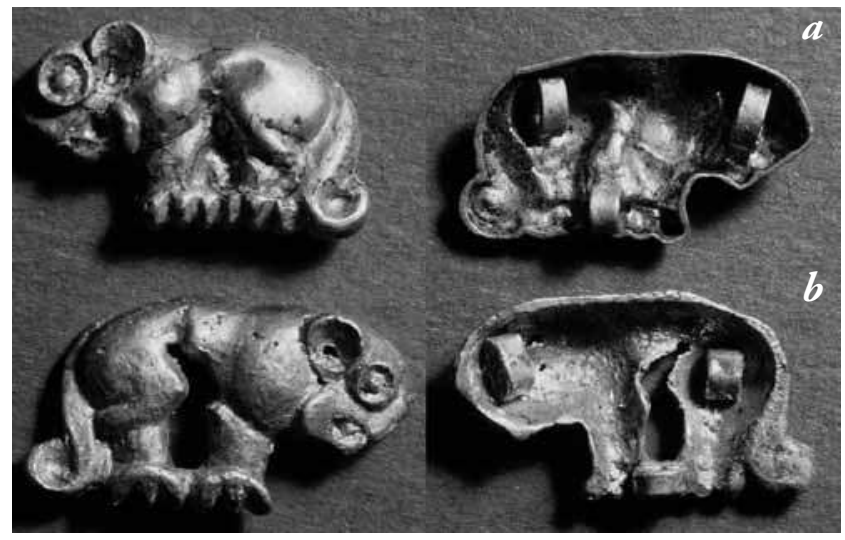

Figure 2: (See colour plate) Panther figures serial production; a: cast in lost wax; b: pressed sheet technique.

Figure 2: (Voir planche couleur) Figures de panthères fabriquées en série; a) fonte à la cire perdue; b) technique de pression sur tôle. 

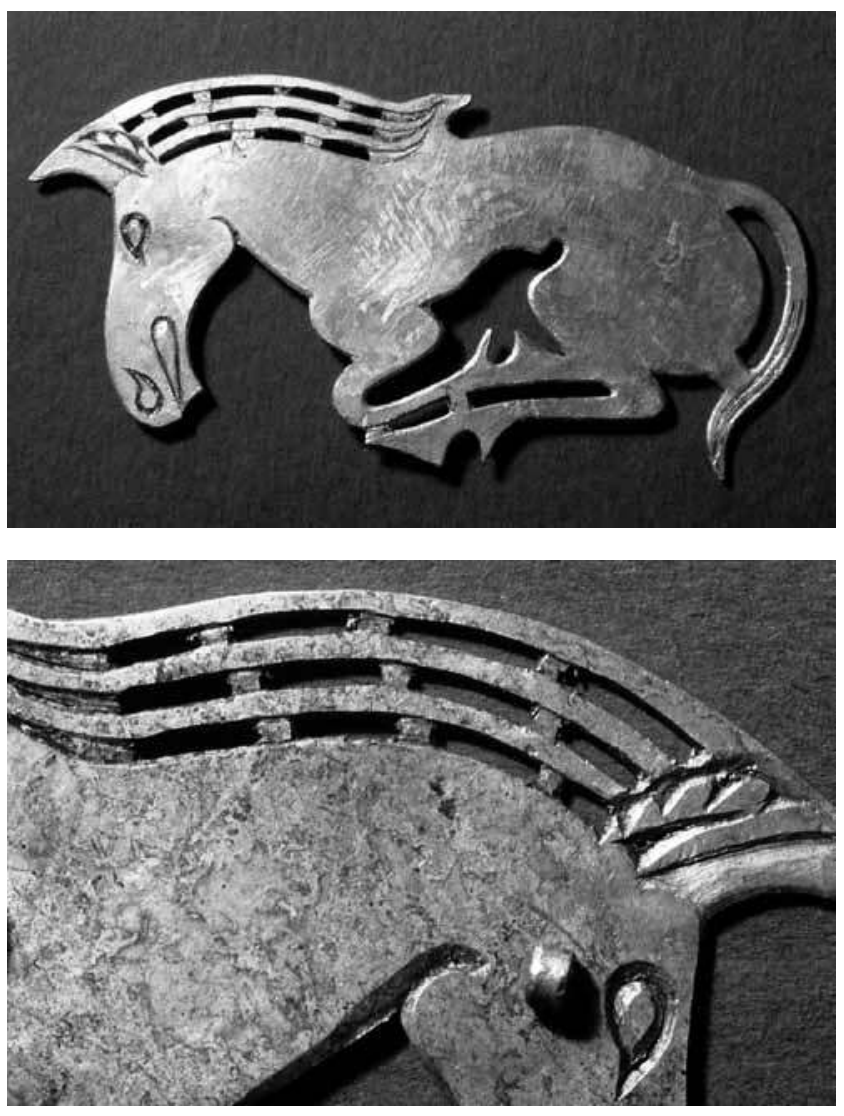

Figure 3: (See colour plate) Flat sheet ornaments, with cut contours and decorated with engraving and open work: horse figure from the woman's head ornament.

Figure 3 : (Voir planche couleur) Ornements en tôle plane, avec des contours découpés, décoration gravée et ajourée : cheval de l'ornement de tête de la femme.

bear a motif of fish scales. These scales are in relief, which was transferred to the golden sheet by the pressed sheet technique. The wood was left as a backing, strengthening the gold sheet element. The quiver, composed of the wooden fitting, the ornamental gold sheet, a leather recipient and strap, had to withstand the weight of bow and arrows.

\section{Filigree and granulation (Fig. 4)}

Wire of up to a diameter of one millimetre in thickness was produced by manual hammering. Small rings made of wire served for the production of chains made of simple loops or with the loop-in-loop technique (Fig. 5) (Reist Stark and Reist Smith, 2000). Very fine wires for filigree and the outline of the enamel panel were produced by coiling a narrow gold strip, a procedure well known from ancient wire, the so-called 'strip-twisting' (Formigli, 1993).

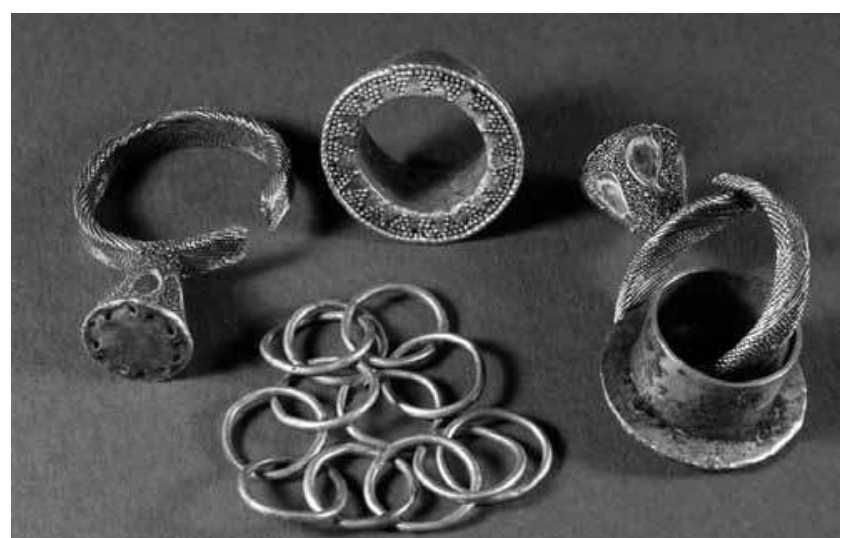

Figure 4: (See colour plate) Sheet work, decorated with filigree, granulation and enamel: ear plugs and pendants with chain.

Figure 4: (Voir planche couleur) Travail de la tôle, décorée avec du fligrane, de la granulation et de l'émail : pendants d'oreille et pendentifs avec chaînes.

Helicoidal tool marks of this technique are clearly present on gold wire decorating the sheet animal figures, boots, decorative bands, and the headgear. Fine filigree wires were fixed on the metal support by soldering with metallic solder, as shown by clearly visible traces of solder.

Granulation and filigree are decorative techniques based on the application of granules or fine wires on a metal sur-

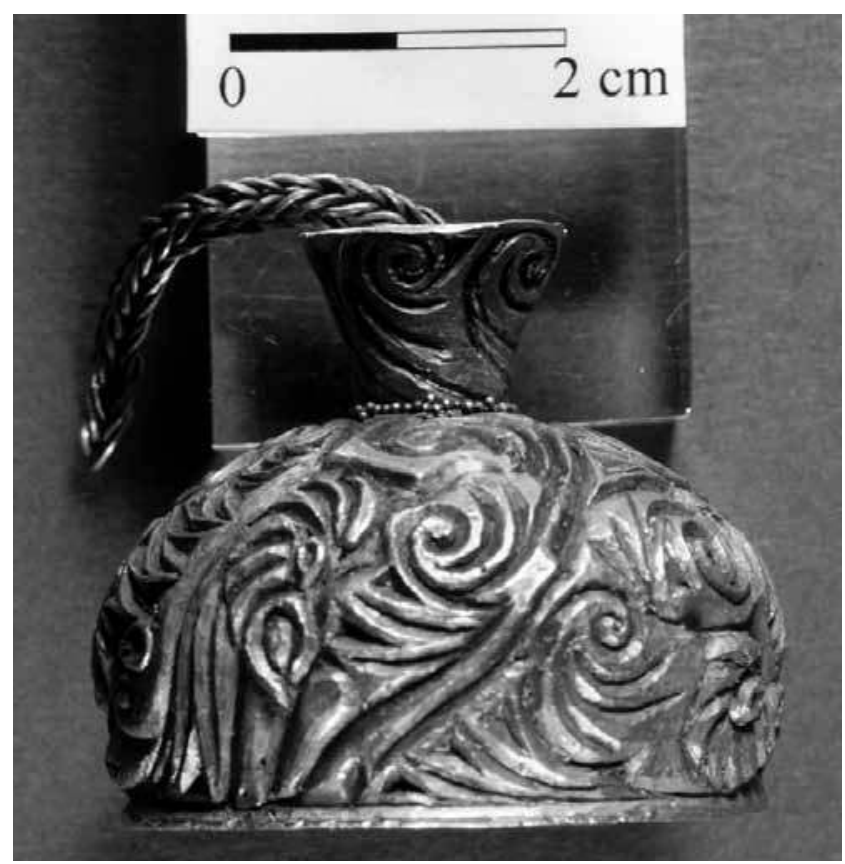

Figure 5: Loop-in-loop chain: miniature cauldron with chain.

Figure 5: Chaîne en loop-in-loop: chaudron en miniature avec chaîne. 
face attached by soldering (Wolters, 1986; 1987). Both techniques of decoration were also applied in combination with enamel. Enamel was already well developed in early Scythian art. Metallic solder was used for hot joining. This solder is a gold alloy whose melting point is lower than that of the base metal. Small particles were placed on the surface to be joined and then melted. Remnants of solder are clearly recognizable on the gold work.

In addition to soldering, riveting and folding were also used as joining techniques in the gold work from Arzhan 2. Ear ornaments (Fig. 4), decoration bands from the boots, zoomorphic sheet figures, and beads from Arzhan are outstanding examples of enamelled filigree and granulation work. Enamel is used here as a pale whitish glass on gold sheet, applied on the metal surface as a crushed powder and then melted in the furnace.

Metal inlay is a polychrome decorative technique present in Arzhan 2 on iron weapons ornamented with gold and silver (Fig. 6). Small precious metal elements were incrusted in the iron surface. These small sheet or wire pieces were hammered and rubbed into grooves executed in advance. For this type of work, hardened steel implements were needed to engrave or cut the grooves and hollows. The spectacular iron weapons of the prince of Arzhan were already highly complex, three-dimensional and ornamental works of art created by a blacksmith, before the fine metalworker began to add the gold and silver inlay.

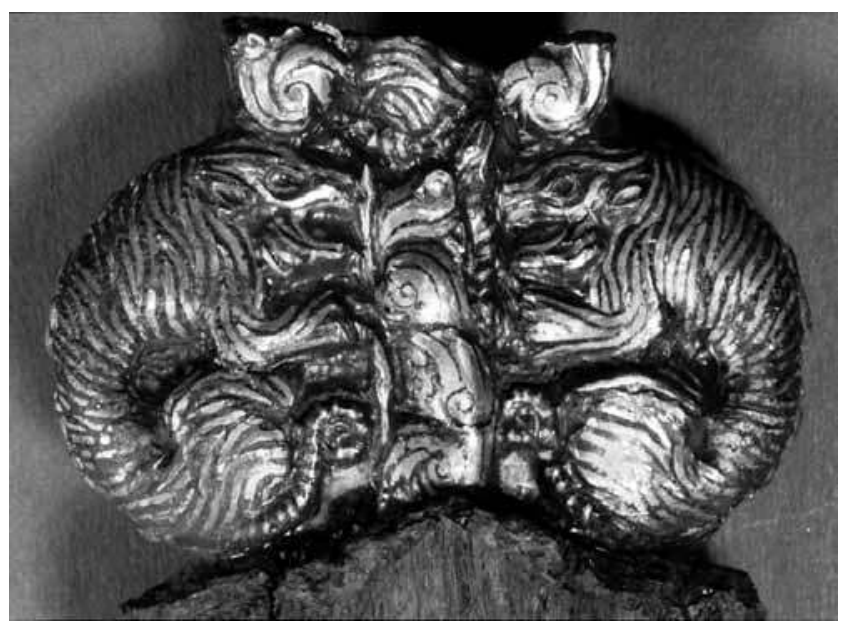

Figure 6: (See colour plate) Gold inlay in iron weapons: detail of the man's dagger.

Figure 6: (Voir planche couleur) Incrustations d'or dans des armes en fer: détail du poignard de l'homme.

\section{WORKSHOP GROUPS}

Different technical workshop groups from Arzhan 2 can be distinguished. One group consists of cast objects, massif and hollow, with 'kerbschnitt' relief, made by lost wax casting (Figs. 1 and 2a). Another category consists of flat sheet ornaments, with cut contours and decorated with engraving and openwork (Fig. 3). Sheet working was also identified on three dimensional, hollow sheet ornaments worked with dies or by chasing. Flat sheet work, decorated with filigree, granulation and enamel represents yet another group (Fig. 4). Serial production of identical articles is evident in numerous objects cast in lost wax, and others worked in pressed sheet (Fig. 2). The next group contains wire work, such as simple loop and loop-in-loop chains (Fig. 5). Finally, gold and silver inlay in iron weapons constitutes the last group in the assemblage of fine metal work (Fig. 6).

The different fine metal working techniques used in the manufacture of the gold and iron artefacts from Arzhan 2 were not new inventions. They were previously known in other regions, such as the Near East, as well as China, before the $7^{\text {th }}$ century BC, while lost wax casting, soldering, filigree and granulation, and also polychrome metal inlay, were also in use in Anatolia and Mesopotamia, as well as in Iron Age Europe. However, this discovery represents the first instance of the application of such a wide range of metal working techniques in the production of objects in the Scythian animal style.

The gold technology in Arzhan 2 can be summed up according to technical categories as follows:

\section{Casting techniques:}

$\checkmark$ ingot casts for sheet and wire production

$\diamond$ lost wax casting, massif and hollow single pieces and series

Plastic shaping techniques:

$\checkmark$ flat hammered sheet; chased sheet with repoussé

$\checkmark$ pressed sheet, serial production with dies

$\diamond$ wire production, chains

\section{Joining techniques:}

$\diamond$ soldering, riveting, folding

\section{Decorative techniques:}

$\checkmark$ cast relief, finished by scraping and chiselling

$\checkmark$ cut decoration: engraving, chiselling, open work

$\checkmark$ application of small elements: granulation and filigree (solder) 
$\checkmark$ enamel (colour spots)

$\diamond$ inlay: iron objects with precious metal inlay (polychrome)

Finishing techniques:

$\diamond$ grinding and polishing

$\diamond$ pickling with acids

\section{Concluding Remarks}

The exceptional discovery of the intact elite burial of Arzhan 2 provides new insights into the complex gold work of the early Scythians in Siberia. The gold ornaments were worked both for the living and for the dead, some exclusively for ceremonial rituals. They testify to the high technical and artistic level of the complex Scythian goldsmiths' craft in the late $7^{\text {th }}$ century BC. The gold work provides evidence of the organization and specialization of applied arts and of extended cultural contacts. The early date of the $2^{\text {nd }}$ half of the $7^{\text {th }}$ century BC proves that the gold work from Arzhan 2 is older than parallels from Kazakhstan, and represents the first evidence of that technology in Scythian Siberia. The particularly rich combination of techniques applied to specific designs seems to be a local feature. However, the sophisticated gold technology, including lost wax casting, soldering, filigree, granulation, and enamel was known prior to the $7^{\text {th }}$ century BC, both in the East and West.

The brief account of the virtuoso and diverse gold work of the early Scythians reveals a sophisticated knowledge of the metal. The tool marks and techniques identified on the artefacts from Arzhan 2 provide evidence of the equipment of the goldsmith's workshop. From ethnological analogies, it is known that the tools of a mobile atelier could easily be transported in a sack over long distances. This observation corresponds to the nomadic lifestyle of the Scythians. Four different craft traditions were identified among the objects under consideration: cast products with 'kerbschnitt' relief, chased and pressed sheet items, objects with granulation, filigree, and enamel, and gold and silver inlay in iron. More than 2500 years ago, early Scythian goldsmiths equipped with a few archaic tools were able to create gold ornaments of high aesthetic and technical level.

\section{Acknowledgements}

The author should like to express her gratitude to Hermann Parzinger for the invitation to study the gold work from Arzhan 2. Konstantin Chugunov provided every assistance during the research stay at the State Hermitage in St Petersburg, where
Svetlana Burshneva kindly supported my investigations in the research laboratories. Anatoli Nagler provided support both in St Petersburg and in Berlin for finishing my task. I am also very grateful to Niamh Whitfield for polishing my English.

\section{References}

Armbruster, B.R., 1995. Traditionelles Goldschmiedehandwerk in Westafrika und bronzezeitliche Metallverarbeitung in Europa. Technologien im ethnoarchäologischen Vergleich. Beiträge zur Allgemeinen und Vergleichenden Archäologie 15: 111-201.

Armbruster, B.R., 2003. Preßblecharbeiten. Technologisches, in H. Beck, D. Geuenich, H. Steuer (eds.), Reallexikon der Germanischen Altertumskunde 23. Berlin and New York, De Gruyter, 409-413.

Armbruster, B.R., 2010. Technologische Aspekte der Goldschmiedekunst aus Arzan 2, in K.V. Chugunov, H. Parzinger, A. Nagler (eds.), Der skythenzeitlichen Fürstenkurgan Arzan 2 in Tuva. Archäologie in Eurasien 26. Berlin, 183-199.

BIEL, J., 1985. Der Keltenfürst von Hochdorf. Stuttgart, Theiss.

Busch, R., 1993. Gold der Skythen. Schätze aus der Staatlichen Eremitage St. Petersburg. Veröffentlichungen des Hamburger Museums für Archäologie und die Geschichte Harburgs Helms-Museum 67. Münster, Wachholtz.

Chugunov, K.V., 2004. Archaeological discoveries in the Valley of the Kings, Tuva. Artifacts from the Arzhan barrow. Exhibition at the Hermitage, Sankt-Petersburg (in Russian).

Chugunov, K.V., Parzinger, H. and Nagler A., 2003. Der skythische Fürstengrabhügel von Aržan 2 in Tuva. Vorbericht der russisch-deutschen Ausgrabungen 2000-2002. Eurasia Antiqua 9: 113-162.

Chugunov, K.V., Parzinger, H. and Nagler A. (eds.), 2006. Der Goldschatz von Arzhan. Ein Fürstengrab der Skythenzeit in der südsibirischen Steppe. München, Schirmer/Mosel.

Chugunov, K.V., Parzinger, H. and Nagler A. (eds.), 2010. Der skythenzeitlichen Fürstenkurgan Arzan 2 in Tuva. Archäologie in Eurasien 26. Berlin.

Formigl, E., 1993. Sulla tecnica di costruzione dei fili d'oro nell'oreficeria etrusca, in C. Eluère (ed.), Symposium "Outils et ateliers d'orfevre des temps anciens". Saint-Germain-en-Laye 1991. Antiquités Nationales, mémoire 2. Saint-Germain-enLaye: Société des Amis du Musée des Antiquités Nationales et du château de Saint-Germain-en Laye, 35-38.

Menghin, W. and Parzinger, H. (eds.), 2007. Im Zeichen des goldenen Greifen. München, Berlin, London, New York, Prestel.

Popescu, G.A., 2001. La pantera e il cervo, in G.A. Popescu, A. Alekseev, J. Piotrovskij (eds.), Siberia. Gli uomini dei fiumi 
ghiacciati. Museo Statale dell' Ermitage, San Pietroburgo. Milano, Electa, 67-77.

Popescu, G.A., Alekseev, A. and Piotrovskij, J. (eds.), 2001. Siberia. Gli uomini dei fumi ghiacciati. Museo Statale dell'Ermitage, San Pietroburgo. Milano, Electa.

Reist Stark, J. and Reist Smith, J. Classical loop-in-loop chains and their derivatives. London, A. \& C. Black.

Schiltz, V., 1994. Les Scythes et les nomades des steppes, VIII siècle avant J.-C.- $-^{e r}$ siècle après J.-C. Paris, Gallimard.
Wolters, J., 1986. Die Granulation. Geschichte und Technik einer alten Goldschmiedekunst. München: Callwey.

Wolters, J., 1987. Filigran, in K.-A. Wirth (ed.), Reallexikon zur Deutschen Kunstgeschichte 8. München, Beck, 1062-1184. 
